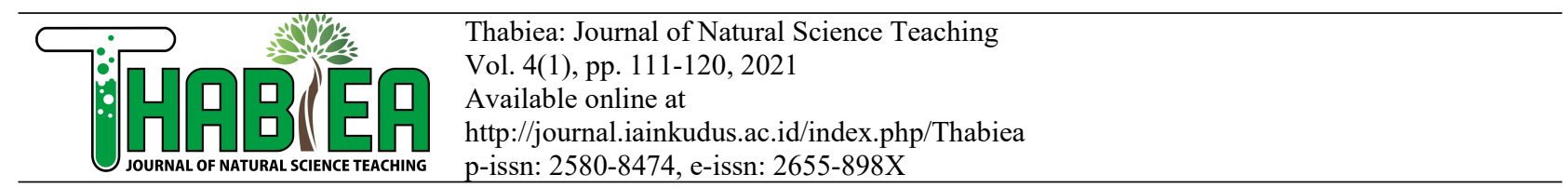

\title{
Biology Blog: Project-Based Learning in Pandemic Periode to Encourage Students' Creativity
}

\author{
Nawawi $^{1 *}$, Eka Trisianawati ${ }^{2}$, Abdul Karim ${ }^{3}$ \\ 1,2 Biology Education Program, IKIP PGRI Pontianak, Ampera Street No. 88, Pontianak City, \\ West Kalimantan, Indonesia \\ ${ }^{3}$ Institut Agama Islam Negeri Kudus, Kudus, Central Java, Indonesia \\ *Correspondence: nawawi@ikippgriptk.ac.id
}

\begin{tabular}{ll}
\hline Kbstract \\
\hline Keywords: & The purpose of this study was to determine the effectiveness of the biology blog \\
Project-Based & project-based learning on the creativity of students and cognitive ability in the e- \\
Creativity & learning course, biology department program IKIP PGRI Pontianak. The method in \\
Biology Blog & this research was quasi-experimental. The research design used in this study was a \\
& nonequivalent control group design, using two groups. The instruments used are; \\
& student creativity test, creativity observation guidelines, cognitive test. The Wilcoxon \\
& test results showed a difference in the effectiveness of using project-based learning \\
& between the pretest-posttest control class and the pretest-posttest experimental class. \\
& Then at the project implementation stage, the results obtained that students have \\
& trained to be collaborative, independent, and creative in making a biology blog. \\
& Meanwhile, based on observations, students have been able to use flexibility skills in \\
& various ways to solve problems when creating biology blogs, integrating text, images, \\
& and videos into blogs. In addition, students use Elaboration skills to develop ideas and \\
details of group assignments in more detail. Thus, this study can conclude that biology & project-based learning effectively improved student creativity in making a biology \\
& blog.
\end{tabular}

To cite this article:

Nawawi, Nawawi., Trisianawati, Eka., Karim, Abdul. (2021). Biology Blog: Project-Based Learning in Pandemic Periode to Encourage Students' Creativity. Thabiea: Journal of Natural Science Teaching, 4(1), 111-120.

\section{Introduction}

Competition among states in the world is pushing peoples to developed power in the industry, including Indonesia that affected competition. Because of that, Indonesia must increase $21^{\text {st }}$ Century Teacher competence followed by the demand in the industrial revolution 4.0 and industrial revolution 5.0, where the current is has been conducted now. Indonesia was one of the largest countries in Southeast Asia should be affected. According to Adzandini \& Tarunasena (2019) Industrial Revolution 4.0, Technology is an amalgamation of physical and digital technology through analytic, artificial intelligence cognitive, technology and the Internet of Things (IoT) used to make decisions right decision.

$21^{\text {st }}$ Century Education appears as a solution in the face of global challenges. The characteristics that stand out in $21^{\text {st }}$ Century education were the integration of science, information, and communication technology that is used in education, for example; the increasing number of online courses (webinars) to master studies and expertise and the development of applications. Applications to support teachers that used to teach students, and gadgets for online learning. The success of the Industrial Revolution 4.0 and the Industrial Revolution 5.0, where biology teacher should be able to understand $21^{\text {st }}$ Century Skill for his 
shelf. Same as Permana (2015) who claimed that $21^{\text {st }}$-century skills should be applied and taught to students. Meanwhile $21^{\text {st }}$-century skills according to Adzandini \& Tarunasena (2019) covering; (1) life and career skills, (2) innovation and learning skills, and (3) information media and technology skills. While $21^{\text {st }}$-century skills are divided into three common skills, namely; (1) information and communication skills; (2) think and solve problem skills, (3) interpersonal skills and self-regulating (Insyasiska et al., 2015).

Making blogs as an educational medium could be used to train $21^{\text {st }}$ Century Skill to prospective biology teachers because a blog can be used to teach in class. According to Muslim (2019) stated that educators could use blogs to display material information, teaching materials that are ready to download, and references in the form of hyperlinks. The $21^{\text {st }}$ Century Skill that biology teachers must possess today is information and technology media skills because a millennial teacher must have the skills to use technology, internet media, blogging, vlogging, and social media as learning media. Meanwhile, based on the results of the study Azifah \& Yunus (2017) obtained that the design of animated blog media can help to learn according to the neds at the high school level in Indonesia.

The Blog can make teaching and learning activities more fun. A blog contains material source that is relevant and can be published to all students and can be accessed by anyone so that the difficulty in gathering information needed in the learning process can be overcome (Azifah \& Yunus, 2017). Therefore, by using a blog as a learning medium that is attractive, interactive, easily accessible to anyone through the application on student cellphone. Meanwhile, according to Wahyudi (2014) blogs are a medium of communication between teachers and students in facilitating the online learning process that consists of text, audio, and video.

Biology education program students do not yet have expertise in creating attractive online learning media with biology content that can be accessed online, containing online questions, online quizzes, and videos that integrated with YouTube. Project-based Learning is a systematic teaching method that engages students in learning important knowledge and $21^{\text {st }}$ century skills through student-influenced inquiry process structured, authentic questions and carefully designed products (Wahyudi \& Winanto, 2018). $21^{\text {st }}$-century skills are needed for a teacher in this era. Due to the conditions of the Covid-19 pandemic, teachers have to teach online, so the ability of teachers to create online media.

Many kinds of research on project-based learning have been carried out, such as research by Insyasiska et al. ( 2015) where project-based learning affects students' learning motivation improves critical thinking skills on viruses and bacteria. According to Rahmazatullaili et al. (2017), a project-based learning model can improve creative thinking skills and problem-solving abilities. Developed student's creative thinking skills through project-based learning to think fluently and think in detail and think original from making natural acid-base indicators (Candra et al., 2019). Meanwhile, there is still little research about making a biology blog carried out in e-learning courses in the biology department program that could be used to help improve student skills and knowledge as prospective biology teachers. Performing assignments in an authentic, relevant, and realistic manner will help understand $21^{\text {st }}$-century skills and increase student creativity through assignments to make blogs. Based on this issue, this study aimed to determine the effectiveness of projectbased learning on the creativity of students in the biology education study program in the biology e-learning course in the Biology Study Program at IKIP PGRI Pontianak.

\section{Method}

This current research explored a quasi-experimental study with a nonequivalent control group design (Insyasiska et al., 2015) . In this design, the experimental group and control group not chosen randomly because of the limited number of classes. The population 
in this study were all 4th-semester students who took e-learning courses in the Biology Education Study Program, IKIP PGRI Pontianak. The purposive sampling technique selected the research sample, where 30 students in 1 class received project-based learning treatment, and as many as 30 other students were in the control class. research design can be described as Table 1.

Table 1. Nonequivalent Control Grup Design with Prestest-Posttest

\begin{tabular}{llll}
\hline Group & Pretest & Treatment & Posttest \\
\hline KE & O1 & X1 & O2 \\
\hline KK & O3 & X2 & O4 \\
\hline
\end{tabular}

Information :

$\mathrm{KE} \quad=$ Experimental class

$\mathrm{KK}=$ Control class

$\mathrm{O} 1=$ Pretest experimental class

$\mathrm{X} 1=$ Learning using project based-learning

$\mathrm{O} 2=$ Posttest after treatmen in the experimental class

$\mathrm{O} 3=$ Control class pretest

$\mathrm{X} 2=$ Learning by not using project-based learning

$\mathrm{O} 4=$ Posttest after treatment in the control class

The independent variable in this study was project-based learning. Meanwhile, the dependent variable was students' creativity and students' cognitive abilities. The control variable in this research was e-learning courses. The instruments in this study include; 1) student creativity observation sheet, 2) product assessment sheet, 3) creativity test using description questions that measure; flexibility, originality, elaboration, and fluency, 4) student cognitive test. Research procedure biology blog project-based learning steps adapted from The Gorge Lucas Education Foundation (Gunawan et al., 2017). It can be explained as Figure 1.

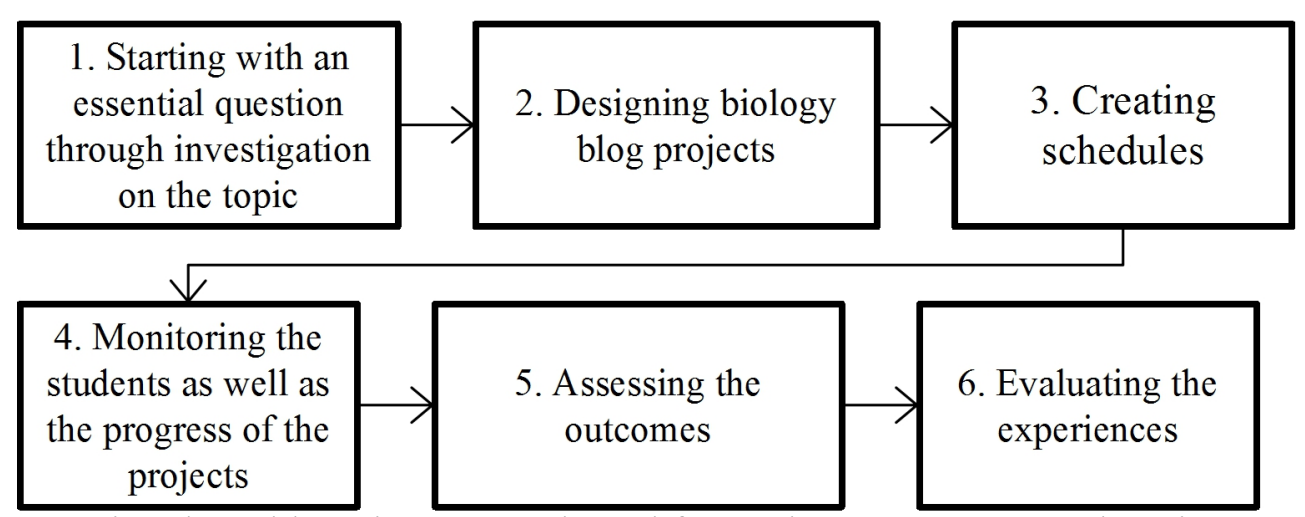

Figure 1. Project-based learning steps adapted from The Gorge Lucas Education Foundation

Cognitive data and creativity data from the pretest and posttest assessments in both classes were then tested statistically with the help of SPSS 25 software to test the effectiveness between the project-based learning class and the control class. The data were not normally distributed based on the cognitive assessment results, so the effectiveness analysis continued with a non-parametric test, namely the Wilcoxson test. The flow of research carried out is as Figure 2. 


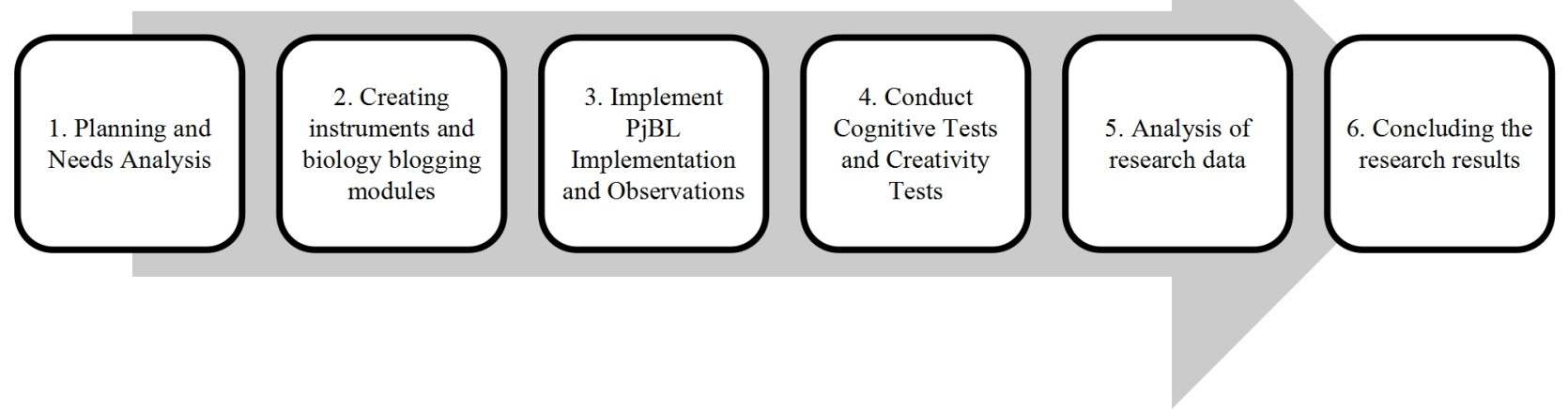

Figure 2. Research flow biology blog project-based learning

Meanwhile, the observation data of students' creativity is an assessment of the creative design process of a project. Data analyzed using the percentage formula state (Sari \& Angreni, 2018). The level of students' creativity is shown in Table 2.

Information :

$$
N K=\frac{X}{X m}
$$

$\mathrm{NK}=$ The Value of creativity

$\mathrm{X}=$ Score obtained

$\mathrm{Xm}=$ Maximum score

(Sari \& Angreni, 2018)

Tabel 2. Level of students' creativity in making product (Biology Blog) Percentage (\%) Level of students' creativity

\begin{tabular}{ll}
\hline $\mathbf{8 1 - 1 0 0}$ & Very High \\
\hline $\mathbf{6 1 - 8 0}$ & High \\
\hline $\mathbf{4 1 - 6 0}$ & Moderate \\
\hline $\mathbf{2 1 - 4 0}$ & Low \\
\hline $1-20$ & Very Low \\
\hline
\end{tabular}

\section{Results and Discussion}

The implementation of project-based learning in this research refers to The Gorge Lucas Educational Foundation by Gunawan et al. (2017) Project-based learning begins with starting with an essential question, designing projects, creating schedules, monitoring the students, and the progress of the projects, assessing the outcomes and evaluating the experiences. Meanwhile, the implementation of Project-Based Learning started with essential questions. The examples of the questions were "How to create media that can be accessed by students anywhere and anytime?". The question requires students to work on an assignment in conducting certain activities to solve the problem.

Based on those essential questions, the lecturer and the students collaboratively designed the project plan. In this study, the planned project was to make a blog as a biology media education. Scheduling is also made collaboratively between lecturers and students. This stage includes several blogging activities carried out independently by students and practicing in a computer laboratory together with the lecturers. Lecturers are responsible for monitoring student activity and on the progress blog creation project. The monitoring process 
carried out using a rubric to record student's activities. The product assesses by using product observation sheets. Lecturers provide input and suggestions to students after conducting product assessments. Based on the normality test data using SPSS 25 , it could see at that the data was not normally distributed so that it is continued with the Wilcoxson test.

Table 3. The results of $Z$ value and Asump Sig (2-tailed) on the Wilcoxson test

\begin{tabular}{lll}
\hline Test Statistics $^{\mathrm{a}}$ & & \\
\hline & $\begin{array}{l}\text { Pretest_control } \\
\text { Posttest_control }\end{array}$ & $\begin{array}{l}\text { - Pretest_exp } \\
\text { Posttest_exp }\end{array}$ \\
\hline $\mathbf{Z}$ & $-4.560^{\mathrm{b}}$ & $-4.624^{\mathrm{b}}$ \\
\hline Asymp. Sig. (2-tailed) & .000 & .000 \\
\hline
\end{tabular}

Based on the results of the Wilcoxon Signed Rank Test calculation on the cognitive ability that could be seen in Table 3 . The control class obtained a $Z$ value of $-4,560$ which is less than 0.05 . While the experimental class $Z$ value is $-4,624$ where it is less than 0.05 , the hypothesis decision is to accept $\mathrm{Ha}$ or which means there is a difference in the effectiveness of using Project-based learning between the pretest-posttest control class and the pretestposttest experimental class.

This finding is consistent with the results of previous research by (Insyasiska et al., 2015; Lukman et al., 2015) that the project-based learning model is proven to have a significant effect on improving learning outcomes and creativity. Motivated students will work with the team to produce blog designs and creative content, which are realized in a product. Meanwhile, Insyasiska et al. (2015) Through PJBL can improve students' cognitive abilities starting from analyzing, synthesizing, evaluating, and creating. PJBL is proven to affect the learning outcomes of students because it presents authentic problems that occur today in distance learning.

Based on the normality test results on the students' creativity test results, this test measures flexibility, originality, elaboration, and fluency. According to Rahmazatullaili et al. (2017), the creative thinking ability test instrument could be developed in the form of essay questions using indicators of fluency, flexibility, originality, and elaboration. While the results of the research conducted obtained creativity data normally distributed. This normality means that both classes have the same creativity. These results can be seen in the Table 4 .

Table 4. Normality Test Results for Flexibility, Originality, Elaboration, and Fluency

\begin{tabular}{llllll}
\hline \multirow{2}{*}{ Flexibility } & \multirow{2}{*}{ Class } & \multicolumn{3}{l}{ Kolmogorov-Smirnov } & \multirow{2}{*}{ Conclusion } \\
\cline { 2 - 5 } & & Statistic & Df & Sig. & \\
\cline { 2 - 5 } & Control Class & .157 & 30 & .057 & Normal Data \\
\cline { 2 - 5 } Originality & Cxperimental Class & .155 & 30 & .064 & Normal Data \\
\cline { 2 - 5 } & Experimental Class & .153 & 30 & .183 & Normal Data \\
\hline \multirow{2}{*}{ Elaboration } & Control Class & .113 & 30 & $.200^{*}$ & Normal Data \\
\cline { 2 - 5 } & Experimental Class & .073 & 30 & $.200^{*}$ & Normal Data \\
\hline Fluency & Control Class & .158 & 30 & .055 & Normal Data \\
\cline { 2 - 5 } & Experimental Class & .175 & 30 & .019 & Abnormal data \\
\hline
\end{tabular}

Based on the results of observations made in the experimental class, Students use flexibility skills in various ways to solve problems when creating a blog, integrating text, images, and videos into a blog. Students use Elaboration skills to develop ideas and detail tasks in groups in more detail. The lecturer could now from the evidence in the blog creation 
plan and the division of tasks. Mastering ICT and the internet can be their capital to develop more creative learning (Wahyudi \& Winanto, 2018). The academic atmosphere for working on a good project can affect students. This opinion is in line with Tsai et al. (2015) which state that a positive learning environment can positively influence student motivation and creativity. Meanwhile, the observation data of student creativity in making a blog as a product can show in the Table 5.

Table 5 . Student creativity for making product (Biology Blog)

\begin{tabular}{llllll}
\hline & \multicolumn{5}{c}{ Student Creativity } \\
\cline { 2 - 6 } Class & Very High & High & Medium & Low & Very Low \\
\hline Control Class & 5 & 25 & 0 & 0 & 0 \\
\hline Experimental Class & 10 & 20 & 0 & 0 & 0 \\
\hline
\end{tabular}

Due to pandemic conditions, the blog creation project carried out online and offline, while offline activities carried out at the IKIP PGRI Pontianak computer laboratory are limited by following health protocols as shown in Figure 3. Students work in groups to create blogs so that students are trained to communicate, collaborate, think critically, solve problems, master digital skills. In line with Dewi (2015) $21^{\text {st }}$-century skills such as digital and literacy skills, creativity, innovation, and able to collaborate must be owned and developed by students. While lecturers share tutorials online using the WhatsApps and Youtube application. Sukardi et al. (2021) in learning biology at SMA Negeri 1 Ponorogo stated that students prefer online learning using WhatsApp and google classroom in collecting assignments.
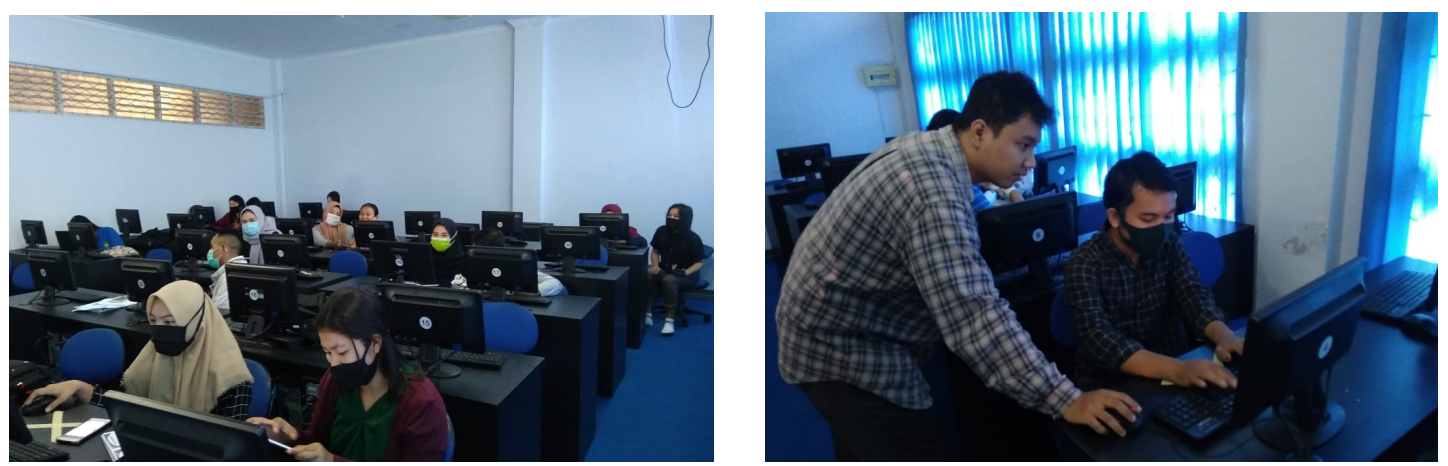

Figure 3. Students working on a blogging project in a computer laboratory

In making a biology blog using Project-based learning, the ability to work together, students' motivation to learn, and the sense of responsibility of students will increase. In line with Lukman et al. (2015) Student's project requires students to explore knowledge from various sources around them, including from classmates. Moreover, the students seemed very enthusiastic about making blogs in the computer laboratory. Similar to Kacetl \& Semradova (2020) E-learning can change the roles of teachers and students, where e-learning is exciting because it can increase the clarity of instruction and the integrity of learning, the individual learning process, and feedback. Through Project-based learning, the teacher could develop the ability to provide and carry out new ideas and see a problem from a different perspective in the creative predicate (Wijayati et al., 2019).

The implementation of Biology Blog Creation carried out in the experimental class refers to the project-based learning syntax adapted from The Gorge Lucas Education Foundation (Gunawan et al., 2017). The explanation is as follows; The first step began with an essential question by investigating the topic. At this stage, students attempt to answer the question of how to create an exciting biology blog?. So students try to do literacy studies and look for examples of biology blogs and websites to see how the graphics, button arrangement, 
video, and text on the blog. Then in the second stage, designing a biology blog project, each student carried out in a computer laboratory. However, due to time constraints and restrictions due to the increase in pandemic cases in the city of Pontianak, learning continues online. Students communicate with lecturers via WhatsApp to get suggestions and input from lecturers. The third step in project-based learning is to make a schedule. The implementation of activities cannot be completed in one meeting, so students develop a schedule to convey the project's progress. The lecturer carries out the fourth step in project-based learning by monitoring the project's progress before the results are finally assessed. The biology blogs produced by students can be seen in Figure 4.
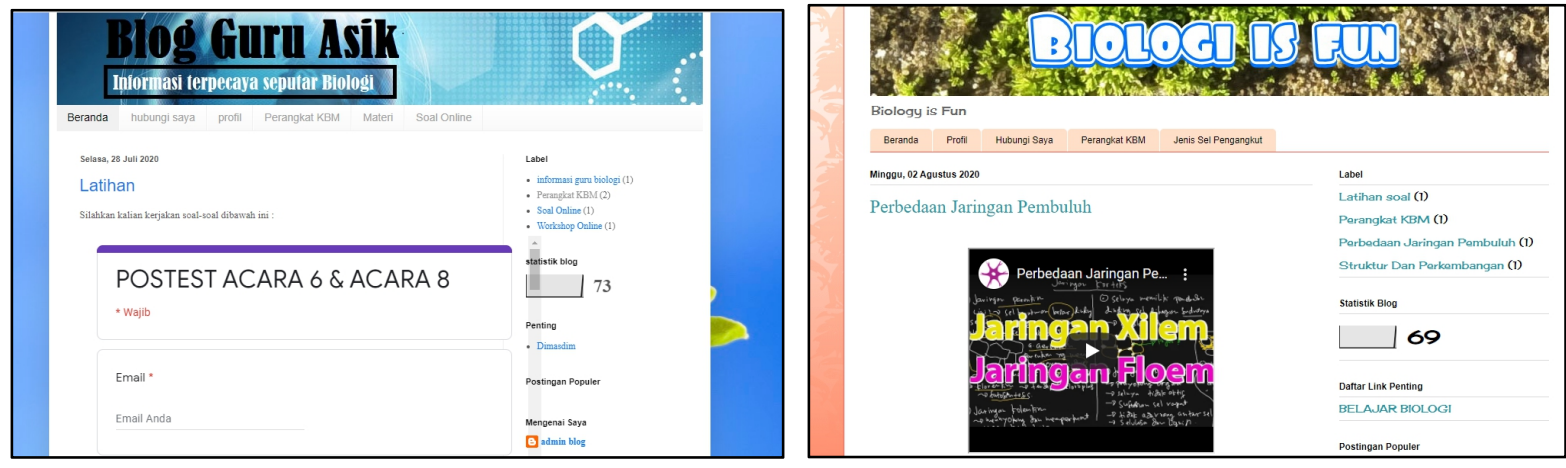

Figure 4. Students' blogging product with the addresses to access, namely: https://dimasbiologi.blogspot.com \& https://murdipah.blogspot.com

It can be seen that students have been able to integrate online learning videos from Youtube into the blog page. Students have also created online questions using google formulas to appear on the biology blog page they have created, and it makes the biology blog more interactive. The appearance of the biology blog looks interesting because students have been able to make headers that are up and following the theme chosen by each student. The results of making blogs between individuals in the experimental class show different designs or appearances. By making a blog, we know that each student has a high level of originality in making designs because every student makes them with pleasure and wants to show their best work. Anyone can access student blogs at any time and anywhere. Because biology blogs created using Blogspot are free.

The biology blog created by experimental class students in Figure 4 looks very interactive and exciting to make users interested in learning biology material. In line with Muslim (2019), the integration of blogs in learning activities will make learning more quality both input and output. Meanwhile, according to Wijayati et al. (2019), project-based learning can increase students' learning motivation, knowledge, and creativity, because in doing projects, students always discuss to solve the problems they face. Through creating a biology blog, students are mastered technology skills. Meanwhile, according to Nuraini (2017), biology teachers must have self-regulation skills, critical thinking, creativity, information and digital literacy, and problem-solving skills and technology skills.

Through problem-based learning conducted in the e-learning course, students in the experimental class can overcome obstacles in creating a biology blog. Students who can overcome the problem are students who already have one of the 21 st-century abilities. In line with Wijaya et al. (2016), mastering information media and technology (ICT) is one of the 21st-century skills that students must master to support careers and future challenges. Meanwhile, according to Pratiwi et al. (2019), 21st-century skills will encourage students to have in-depth knowledge and understanding of the importance of lifelong learning. 21st- 
century skills are also known as 4C, namely; critical thinking, creativity, communication, and collaboration (Redhana, 2019). By making a biology blog, students become more creative in creating material content. The blogs created are equipped with text and images and are also equipped with videos, interactive questions using google formulas, and varied background backgrounds. It same as Redhana's (2019) learning and innovation skills focusing on critical thinking, creativity, communication, and innovation.

Project-based learning provides opportunities for students to learn concepts in depth while also improving their learning outcomes (Arizona et al., 2020). Meanwhile, Chasanah et al. (2016), The project-based learning model is more effective than conventional learning models to improve students' creative thinking and science process skills. By using projectbased learning, students of the biology study program IKIP PGRI Pontianak could have the ability to communicate, collaborate, solving the problem using many options from discussion with another. Integrating text, video, and picture in one education media such as a blog was one of the 21 st-century skills.

\section{Conclusion}

Based on the research, project-based learning provides more effective results than learning in the control class. Meanwhile, project-based learning is more practical to use in helping students create a biology blog. Project-based learning could allow students to use flexibility skills to solve problems when creating biology blogs, integrating text, images, and videos into blogs. Making interesting biology blogs can make students develop their creativity as one of the 21 st-century skills. In addition, students use elaboration skills to develop ideas and details of group assignments in more detail. Thus, this study can conclude that biology project-based learning effectively improved student creativity in making a biology blog.

\section{Acknowledgment}

Support for this project was funded by research and development center institutions IKIP PGRI Pontianak grant. We would like thanks to the Head of a research institute, Biology lecturer, and student of the Education Biology Study Program, and everyone who helps with this research. The researcher would like to thank the editors and managers of the Thabiea journal for the opportunity given to publish in the Thabiea Journal.

\section{References}

Adzandini, V. N., \& Tarunasena, T. (2019). Proyek Vlog Untuk Meningkatkan Kreativitas Siswa Dalam Pembelajaran Sejarah. FACTUM, 8(2), 237-246. https://doi.org/10.17509/factum.v8i2.22154

Arizona, K., Abidin, Z., \& Rumansyah, R. (2020). Pembelajaran Online Berbasis Proyek Salah Satu Solusi Kegiatan Belajar Mengajar Di Tengah Pandemi Covid-19. Jurnal Ilmiah Profesi Pendidikan, 5(1), 64-70. https://doi.org/10.29303/jipp.v5i1.111

Azifah, N., \& Yunus, Y. (2017). Perancangan dan Pembuatan Blog Animatif Mata Pelajaran Teknologi Informasi dan Komunikasi (TIK) Kelas XI ( Studi Kasus SMA Baiturrahmah Padang ). Jurnal Pendidikan Dan Teknologi Informasi, 4(1), 180-190. http://lppm.upiyptk.ac.id/pti/index.php/pti/article/view/38

Candra, R. A., Prasetya, A. T., \& Hartati, R. (2019). Analisis Kemampuan Berpikir Kreatif Peserta Didik Melalui Penerapan Blended Project Based Learning. Jurnal Inovasi Pendidikan Kimia, 13(2), 2437-2446. https://journal.unnes.ac.id/nju/index.php/JIPK/article/view/19562 
Chasanah, A. R. U., Khoiri, N., \& Nuroso, H. (2016). Efektivitas Model Project Based Learning terhadap. Jurnal Penelitian Pembelajaran Fisika, 7(1), 19-24. http://ejurnal.upgrismg.ac.id/index.php/JP2F

Dewi, F. (2015). Proyek Buku Digital: Upaya Peningkatan Keterampilan Abad 21 Calon Guru Sekolah Dasar Melalui Model Pembelajaran Berbasis Proyek. Metodik Didaktik: Jurnal Pendidikan Ke-SD-An, 9(2), 1-15. https://doi.org/10.17509/md.v9i2.3248

Gunawan, G., Sahidu, H., Harjono, A., \& Suranti, N. M. Y. (2017). The Effect of Project Based Learning With Virtual Media Assistance on Student's Creativity In Physics. Cakrawala Pendidikan, XXXVI(2), 167-178. https://doi.org/10.21831/cp.v36i2.13514

Insyasiska, D., Zubaidah, S., \& Susilo, H. (2015). Pengaruh Project Based Learning Terhadap Motivasi Belajar, Kreativitas, Kemampuan Berfikir Kritis, dan Kemampuan Kognitif Siswa Pada Pembelajaran Biologi. Jurnal Pendidikan Biologi, 7(1), 9-21. https://doi.org/10.17977/um052v7i1p9-21

Kacetl, J., \& Semradova, I. (2020). Reflection on blended learning and e-learning - case study. Procedia Computer Science, 176, 1322-1327. https://doi.org/10.1016/j.procs.2020.09.141

Lukman, L. A., Martini, K. S., \& Utami, B. (2015). Efektivitas Metode Pembelajaran Project Based Learning (PjBL) Disertai Media Mind Mapping Terhadap Prestasi Belajar Siswa Pada Materi Pokok Sistem Koloid Di Kelas XI IPA SMA Al Islam 1 Surakarta Tahun Ajaran 2013/2014. Jurnal Pendidikan Kimia (JPK), 4(1), 113-119. https://jurnal.fkip.uns.ac.id/index.php/kimia/article/view/5180

Muslim, B. (2019). Pelatihan Pembuatan Blog Bagi Guru SMPN 8 Kota Pagaralam. NABDIMAS, 2(1), 18-30. https://doi.org/10.36050/ngabdimas.v2i1.223

Nuraini, N. (2017). Profil Keterampilan Berpikir Kritis Mahasiswa Calon Guru Biologi Sebagai Upaya Mempersiapkan Generasi Abad 21. Didaktika Biologi: Jurnal Penelitian Pendidikan Biologi, 1(2), 89-96.

Permana, F. H. (2015). Pengembangan Buku Ajar Biologi Berbasis Blended Learning sebagai Bekal Hidup Di Abad 21 Untuk Mahasiswa S1 KIMIA FMIPA UM. In Prosiding Seminar Nasional Pendidikan Biologi, 58, 50-61.

Pratiwi, S. N., Cari, C., \& Aminah, N. S. (2019). Pembelajaran IPA Abad 21 dengan Literasi Sains Siswa. Jurnal Materi Dan Pembelajaran Fisika (JMPF), 9(1), 34-42. https://doi.org/10.20961/jmpf.v9i1.31612

Rahmazatullaili, R., Zubainur, C. M., \& Munzir, S. (2017). Kemampuan berpikir kreatif dan pemecahan masalah siswa melalui penerapan model project based learning. Beta: Jurnal Tadris Matematika, 10(2), 166-183. https://doi.org/10.20414/betajtm.v10i2.104

Redhana, I. W. (2019). Mengembangkan Keterampilan Abad Ke-21 Dalam Pembelajaran Kimia. Jurnal Inovasi Pendidikan Kimia, 13(1), 2239-2253. https://journal.unnes.ac.id/nju/index.php/JIPK/article/view/17824

Sari, R. T., \& Angreni, S. (2018). Penerapan Model Pembelajaran Project Based Learning (PjBL) Upaya Peningkatan Kreativitas Mahasiswa. Journal of Varia Pendidikan (Varidika) , 30(1), 79-83. 
Sukardi, S., Handayani, I. I., \& Nawawi, N. (2021). Biological Learning Adaptation During The Covid-19 Pandemic Period In Ponorogo 1 Public High School. Acitya: Journal of Teaching \& Education, 3(1), 95-104. http://journals.umkt.ac.id/index.php/acitya

Tsai, C. Y., Horng, J. S., Liu, C. H., Hu, D. C., \& Chung, Y. C. (2015). Awakening Student Creativity: Empirical Evidence In A Learning Environment Context. Journal of Hospitality, Leisure, Sport and Tourism Education, 17, 28-38. https://doi.org/10.1016/j.jhlste.2015.07.004

Wahyudi, N. (2014). Pemanfaatan Blog Sebagai Media Pembelajaran Interaktif. Jurnal Study Islam Panca Wahana, 12(10), 84-94. https://core.ac.uk/download/pdf/234800326.pdf

Wahyudi, W., \& Winanto, A. (2018). Development of Project-based Blended Learning (PjB2L) Model To Increase Pre-Service Primary Teacher Creativity. Journal of Educational Science and Technology (EST), 4(2), 91. https://doi.org/10.26858/est.v4i2.5563

Wijaya, E. Y., Sudjimat, D. A., \& Nyoto, A. (2016). Transformasi Pendidikan Abad 21 Sebagai Tuntutan Pengembangan Sumber Daya Manusia di Era Global. Prosiding Seminar Nasional Pendidikan Matematika 2016, 1, 263-278. https://core.ac.uk/download/pdf/297841821.pdf

Wijayati, N., Sumarni, W., \& Supanti, S. (2019). Improving Student Creative Thinking Skills Through Project Based Learning. KnE Social Sciences, 2019, 408-421. https://doi.org/10.18502/kss.v3i18.4732 